
cited.

\title{
PERLINDUNGAN HUKUM TERHADAP KONSUMEN ATAS PEREDARAN JAJANAN ANAK SEKOLAH BERDASARKAN UNDANG-UNDANG NOMOR 8 TAHUN 1999 dan UNDANG- UNDANG NOMOR 18 TAHUN 2012 (STUDI TERHADAP PERMEN JELI STIK TAHUN 2018 DI KENDAL)
}

\begin{abstract}
A.M. Tri Anggraini
(Dosen Fakultas Hukum Universitas Tarumanagara. Meraih Sarjana Hukum pada Fakultas Hukum Universitas Gajah Mada., Magister Hukum pada Fakultas Hukum Universitas .Tarumanagara.., Doktor (Dr.) pada Fakultas Hukum Universitas.Indonesia )
\end{abstract}

(E-mail: anna.mta@trisakti.ac.id.)

\section{Marcella Wanda Raditya}

(Mahasiswa Program S1 Fakultas Hukum Universitas Tarumanagara)

Received: 22 April 2019; Accepted: 29 Mei 2019; Published: 10 Juni 2019

\begin{abstract}
Technological advances have brought rapid and significant changes to the food industry. By using modern technology, the food industry is now able to produce on a very large scale including a variety of products with a very wide "range". Public consumption of imported and local food products tends to increase. Businessmen are aggressively encouraging consumers to consume excessively and often irrationally, so many incident that are suffered by consumers related to School Children Snack Food Like the incident that just happened in October 2018, namely poisoning cases of dozens of elementary school children in Kendal after consume stick shaped candy. In this paper the question is how the government controls the circulation of school children snacks, in this case BPOM for the 2018 Candy Jelly Candy case in Kendal and how legal protection for consumers for the circulation of snacks for school children. The method used by the author is a normative method. In its supervision of the School Children Snack Food, BPOM has taken steps in the task procedures and supervision functions. However, consumer cases occur related to School Children Food Snacks, actually caused by the three pillars of SisPOM that have not worked optimally. Business actors must comply with all procedures and conditions for distribution of processed food permits in accordance with existing regulations, BPOM must optimize its duties and functions as supervisors and consumers must always be smart and careful in choosing food products
\end{abstract}

Keywords: Perlindungan Konsumen, Hak Konsumen, Pelaku Usaha, Badan Pengawas Obat dan Makanan, Permen Jeli Stik

\section{PENDAHULUAN}

\section{A. Latar Belakang}

Pangan adalah segala sesuatu yang berasal dari sumber hayati, baik yang diolah maupun tidak diolah 
sebagai makanan atau minuman bagi manusia. Sedangkan, keamanan pangan adalah kondisi dan upaya yang diperlukan untuk mencegah pangan dari kemungkinan cemaran biologis, kimia, dan zat lainnya yang dapat mengganggu, merugikan, dan membahayakan kesehatan manusia. ${ }^{1}$

Pangan olahan adalah makanan atau minuman hasil proses dengan cara tertentu dengan atau tanpa bahan tambahan. Setiap orang yang hendak memproduksi pangan olahan untuk diperdagangkan wajib menerapkan tata cara pengolahan pangan sesuai regulasi yang ada khususnya syarat-syarat izin edar dari BPOM.

Pangan yang memenuhi syarat dapat dikenali dari, nomor pendaftaran yang dikeluarkan oleh Badan Pengawas Obat dan Makanan baik nama produk, daftar bahan yang digunakan, berat bersih atau isi bersih, nama dan alamat pihak yang memproduksi atau memasukkan pangan tersebut ke wilayah Indonesia, dan batas waktu daluarsa, wadah/kemasan pangan, penampilan

\footnotetext{
${ }^{1}$ Indonesia, Undang-Undang No.18 Tahun 2012 tentang Pangan.
}

fisik pangan, baik bentuk, warna maupun bau, pemeriksaan kimia dan mikrobiologi.

Kemajuan teknologi telah membawa perubahan-perubahan yang cepat dan signifikan pada industri pangan, produk-produk pangan dalam waktu yang amat singkat dapat menyebar ke seluruh negara dengan jaringan distribusi yang sangat luas dan mampu menjangkau seluruh lapisan masyarakat.

Konsumsi masyarakat terhadap produk-produk pangan baik yang di import maupun lokal cenderung terus meningkat, sementara pengetahuan masyarakat masih belum memadai untuk dapat memilih dan menggunakan produk pangan secara tepat.

Pihak pelaku usaha promosi secara gencar mendorong konsumen untuk mengkonsumsi secara berlebihan dan seringkali tidak rasional. Maka keraplah terjadi peristiwa yang tidak diinginkan yang diderita oleh konsumen terkait produk-produk makanan yang tidak sesuai dengan standarisasi, khususnya standarisasi yang 
ditetapkan oleh BPOM, khususnya dalam hal ini jajanan anak sekolah yang konsumen terkaitnya adalah anak-anak. Seperti peristiwa yang baru saja terjadi pada Oktober 2018, yaitu kasus keracunan belasan anak sekolah dasar di Kendal setelah mengkonsumsi permen berbentuk stik, hingga akhirnya polda Jawa Tengah mengimbau untuk permen tersebut dihentikan perdagangannya.

Maka dalam penulisan ini yang penulis ingin angkat adalah, perlindungan hukum terhadap konsumen atas peredaran jajanan anak sekolah berdasarkan UndangUndang Nomor 18 Tahun 2012 tentang Pangan, Undang-Undang No 8 tahun 1999 tentang Perlindungan Konsumen. $^{2}$

\section{B. Permasalahan}

Berdasarkan uraian di atas, maka permasalahannya adalah :

1. Bagaimana bentuk pengawasan atas peredaran jajanan anak sekolah oleh pemerintah, dalam hal ini BPOM atas kasus Permen Jeli Stik tahun 2018 di Kendal?

${ }^{2}$ Ibid.
2. Bagaimana perlindungan hukum bagi konsumen atas peredaran jajanan anak sekolah?

\section{Metode Penelitian}

\section{Objek Penelitian}

Penelitian tentang "Perlindungan Hukum Terhadap Konsumen atas Peredaran Jajanan Anak Sekolah berdasarkan Undang-Undang Nomor 8 Tahun 1999 tentang Perlindungan Konsumen dan Undang-Undang Nomor 18 Tahun 2012 tentang Pangan Studi Kasus Permen Jeli Stik Tahun 2018 di Kendal" merupakan penelitian normatif. Sebagai suatu penelitian normatif, maka penelitian ini berbasis pada analisis norma hukum, peraturan perundangundangan, konsepsi-konsepsi yang berkaitan dengan hukum perlindungan konsumen di Indonesia, pendapat para ahli (doktrin), maupun lembaga yang melakukan pengawasan (BPOM) terhadap pangan yang menyangkut keselamatan konsumen.

Pemahaman yang mendalam mengenai norma-norma serta pengaturan tentang perlindungan konsumen dikaji berdasarkan 
Undang-Undang Nomor 8 Tahun 1999 tentang Perlindungan

Konsumen. Undang-Undang ini juga secara implisit menyiratkan tentang metode pendekatan hukum yang digunakan oleh BPOM untuk mengawasi kasus-kasus pelanggaran hukum terhadap konsumen berdasarkan ketentuan hukum perlindungan konsumen.

Berdasarkan jenis dan bentuknya, data yang diperlukan dalam penelitian ini adalah data sekunder yang diperoleh melalui studi kepustakaan. Namun demikian, untuk melengkapi atau mendukung analisis data sekunder, tetap diperlukan wawancara dengan beberapa informan yang dinilai memahami beberapa konsep atau pemikiran yang ada dalam data sekunder, sejauh dalam batas-batas metode penelitian normatif.

Dalam hal ini, data kepustakaan yang tergolong dalam bahan-bahan hukum primer adalah UndangUndang Nomor 8 Tahun 1999 tentang Perlindungan Konsumen secara khusus perbuatan yang dilarang bagi pelaku usaha terdapat pada Pasal 8 sampai dengan pasal 17 .
Undang-Undang ini juga secara implisit menyiratkan tentang BPOM untuk mengawasi pelanggaran dibidang perlindungan konsumen. Guna melengkapi kajian yuridis terhadap kasus yang terjadi di lapangan, ditinjau pula peraturan lain di bidang hukum pangan, UndangUndang Nomor 18 Tahun 2012 tentang Pangan, Ketentuan UndangUndang Hukum Pidana, UndangUndang Nomor 36 tahun 2009 tentang Kesehatan, Peraturan Pemerintah Nomor 28 tahun 2004 tentang Keamanan, Mutu, dan Gizi Pangan, Peraturan Kepala BPOM Nomor 14 tahun 2014.

2. Sifat penelitian

Jenis penelitian yang digunakan penulis pada penelitian ini adalah dengan menggunakan jenis penelitian deskriptif. Data yang diperoleh digunakan memecahkan masalah yang dihadapi, dalam hal ini adalah mengenai perlindungan hukum terhadap konsumen jajanan anak sekolah. ${ }^{3}$

\footnotetext{
${ }^{3}$ Soerjono Soekanto, Pengantar Penelitian Hukum, (Jakarta: Universitas Indonesia UIPRESS, 2005), h. 10
} 
3. Data dan Sumber Data

Berdasarkan jenis dan bentuknya, data yang diperlukan dalam penelitian ini adalah:

a. Data primer

Data primer adalah data yang diperoleh langsung dari sumbernya. ${ }^{4}$ Data primer digunakan sebagai pendukung untuk data sekunder, dimana penulis mencari informasi dari informan dengan menggunakan pedoman wawancara yang dilakukan kepada pihak BPOM.

b. Data Sekunder

Dalam penulisan ini data sekunder adalah data utama. Penulis dalam skripsi ini memperoleh data sekunder dari beberapa bahan, antara lain:

1) Bahan hukum primer, yaitu bahan bahan-bahan hukum yang mengikat ${ }^{5}$ terdiri dari: a) Undang-Undang

Nomor 8 Tahun 1999 tentang Perlindungan Konsumen.

b) Undang-Undang Nomor 18 Tahun 2012 tentang Pangan.

c) Peraturan BPOM Nomor 18 tahun 2012

2) Bahan hukum sekunder, yaitu bahan yang memberikan penjelasan mengenai hal-hal yang berkaitan dengan bahan hukum primer. Antara lain: literature, website, dan makalah yang berkaitan tentang perlindungan hukum serta tanggung jawab terhadap konsumen akibat peredaran jajanan sekolah. ${ }^{6}$

3) Bahan hukum tersier. Dalam hal ini bahan hukum tersier yang digunakan adalah Kamus Besar Bahasa Indonesia. $^{7}$

${ }^{4}$ Ibid., hal. 51.

${ }^{6}$ Ibid.

${ }^{5}$ Ibid., hal. 52.

${ }^{7}$ Ibid. 
4. Pengumpulan data

Pengumpulan data sekunder dilakukan melalui studi kepustakaan dan data primer melalui wawancara dengan menggunakan Pedoman Wawancara. Studi kepustakaan dilakukan di beberapa tempat seperti perpustakaan Universitas Indonesia, perpustakaan Fakultas Hukum Universitas Tarumanagara, dan pengaksesan internet.

\section{PEMBAHASAN}

\section{A. Kronologis Kasus}

$\begin{array}{llll}\text { Guru dan } & \text { Siswa } & \text { SDN } & 01\end{array}$ Ngadiwarno, Kabupaten Kendal hari Selasa (2/10) lalu dihebohkan dengan belasan siswa yang keracunan usai jajan di kantin. Mereka mengeluh mual dan pusing setelah mengkonsumsi sebatang permen.

Permen warna-warni dengan bentuk batang itu sepekan ini memang membuat heboh. Selain di Kendal, sebelumnya juga dikabarkan siswa SD di Cilacap sakit hingga meninggal setelah mengkonsumsi permen serupa dengan merk berbeda.

Dinas kesehatan dan Balai POM sedang uji laboratorium terhadap sampel permen yang dikonsumsi. Di Kendal, permen jelly itu dikonsumsi oleh 14 siswa SDN 01 Ngadiwarno kemudian mereka merasa mual, pusing, dan lemas. Tim medis pun datang untuk memberi pertolongan dan akhirnya 6 di antaranya dirujuk ke Puskesmas Sukorejo 01.

Polisi mengamankan sisa permen yang masih ada di kantin. Pedagang di Pasar Sukorejo yang menjual ke ibu kantin juga dimintai keterangan, polisi juga mengamankan 20 kardus perman jelly itu dari pasar serta mengimbau agar tidak menjualnya lagi.

"Stok yang masih tersedia 20 dus dengan harga dijual kembali Rp 28 ribu per kotak," kata Kabid Humas Polda Jateng, Kombes Agus Triatmaja. Imbauannya untuk permen dalam bentuk jelly tersebut tidak diperjualbelikan lagi.

Kanit Reskrim Polsek Sukorejo Ipda Danang Christian, SH. bersama anggota serta didampingi petugas medis Puskesmas 02 Sukorejo, Selasa (9/10/2019), melakukan pengambilan urine siswa siswi SDN 01 Ngadiwarno Sukorejo Kendal yang pada Minggu (2/10/2018) lalu mengalami keracunan permen Stik Jelly. Kegiatan pengambilan tes urin tesebut juga disaksikan oleh para Guru SD setempat. 
Hal itu dilakukan untuk memenuhi permintaan Dokkes Polres Kendal dan Polda Jateng dalam rangka untuk mengetahui bahwa permen Stik Jelly yang sudah di telan siswa siswi SDN 01 Ngadiwarno tersebut mengandung obat berbahaya (Narkoba) atau tidak. Kantin di sekolahan itu pun tak luput dari pengecekan, apakah masih menjual permen Stik Jelly atau tidak.

Disamping itu Kanit Binmas Polsek Sukorejo Aiptu Andy Yulianto usai kegiatan pengambilan urine memberikan penyuluhan kepada Guru dan siswa siswi SDN 01 Ngadiwarno tentang bahaya narkoba dan obat-obat berbahaya lainya. Terkait hal itu, Kapolsek Sukorejo AKP H. Deko. D berpesan khusus bagi para Guru ditekankan untuk selalu mengawasi siswa-siswinya untuk memilih jajan yang sehat yang ada di lingkungan sekolah.

"Selalu awasi siswa-siswinya untuk memilih jajanan sehat di lingkungan sekolah", pesan Kapolsek Sukorejo. Sementara itu sehunungan dengan kegiatan dan penyuluhan dari Polsek Sukorejo ini dari Kepala Sekolah SDN 01 Ngadiwarno menyampaikan ucapan terima kasih kepada Kapolsek Sukorejo dan anggotanya atas partisipasinya dalam memberikan penyuluhan bagi sekolahnya. ${ }^{8}$

\section{B. Profil Badan Pengawas Obat dan} Makanan

Indonesia harus memiliki Sistem Pengawasan Obat dan Makanan (SisPOM) yang efektif dan efisien yang mampu mendeteksi, mencegah dan mengawasi produk-produk termaksud untuk melindungi keamanan, keselamatan dan kesehatan konsumennya baik di dalam maupun di luar negeri. Untuk itu telah dibentuk BPOM yang memiliki jaringan nasional dan internasional serta kewenangan penegakan hukum dan memiliki kredibilitas profesional yang tinggi.

Kiprah Badan Pengawas Obat dan Makanan dalam hal Peredaran Jajanan Anak Sekolah. Sekolah merupakan rumah kedua bagi anak-anak kita, dimana selain menimba ilmu juga seringnya anakanak makan di lingkungan sekolah. Penyediaan pangan jajanan anak sekolah yang aman merupakan contoh dimana sekolah memiliki peranan penting dalam pencapaian

\footnotetext{
${ }^{8}$ www.jateng.polri.go.id
} 


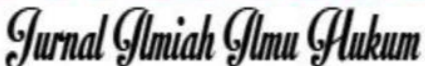

Volume 17, No. 1, Juni 2019

kesehatan terutama kesehatan siswa sekolah. Upaya membentengi siswasiswi SD dari pangan jajanan anak sekolah yang tidak aman terus dilakukan oleh BPOM Pangkalpinang bersama dengan Dinas Kesehatan Kabupaten Belitung, Puskesmas Tanjung Binga dan Kader Keamanan Pangan Desa. Kamis - Sabtu (23-25 Agustus 2018), BPOM melaksanakan sosialisasi 5 kunci keamanan pangan bagi anak sekolah di desa/kelurahan yang di intervensi Gerakan Keamanan Pangan Desa di Kabupaten Belitung. Kegiatan ini dipadukan dengan laboratorium keliling dan fasilitasi keamanan pangan di komunitas sekolah oleh Kader Keamanan Pangan Desa dari masing - masing Desa/Kelurahan.

Kegiatan ini dilaksanakan di 6 SD, yaitu SDN 10 Tanjung pandan dan MIN Tanjung pandan yang terletak di Kelurahan Tanjung pendam pada Kamis 23 Agustus 2018 dan SDN 20 Sijuk dan SDN 21 Sijuk yang berada di Desa Terong pada Jumat 24 Agustus 2018. Pada hari selanjutnya yaitu Sabtu 25 Agustus 2018 kegiatan serupa dilaksanakan di SDN 15 Sijuk dan SDN 16 Sijuk di Desa Keciput. Masing-masing sekolah diikuti oleh sekitar 50 siswa yang didampingi oleh guru - guru mengikuti acara dengan seksama dan riang gembira sambil diselingi kuis dan menyanyikan lagu POMPI.

Selain itu diajarkan juga tentang Cek KLIK agar mereka lebih pintar dalam memilih produk yang akan dibelinya. Dari hasil pengujian sampel jajanan pangan anak sekolah dengan test kit tidak ditemukan adanya kandungan bahan kimia berbahaya seperti Boraks, Formalin, Rhodamin B dan Methanyl Yellow. Namun demikian anak-anak diingatkan untuk waspada juga terhadap adanya bahaya biologis dan bahaya fisik.

Jajanan anak-anak, khususnya yang dijual bebas di luar sekolah masih mengkhawatirkan dan menjadi sorotan Badan Pengawas Obat Dan Makanan (BPOM). Sepanjang tahun 2018, di Provinsi Jawa Timur, BPOM telah menemukan 53 kasus jajanan berbahaya dari 426 sampel jajanan yang di ambil. Ke-53 sampel jajanan tersebut positif mengandung 
bahan kimia berbahaya seperti rhodamin B, formalin, dan boraks. ${ }^{9}$

Beberapa contoh kasus yang terjadi terkait peredaran jajanan anak sekolah

\section{a. Permen narkoba}

Ika Nofitri (35), ibu dari balita berusia 4 tahun membenarkan jika anaknya mengalami hal yang aneh pasca memakan permen pada Jumat (30/3/2018). Menurut Ika Nofitri, malam setelah memakan permen tersebut, anaknya perempuannya tersebut sempat gelisah. Curiga dengan kondisi anaknya, Ika berinisiatif membawanya ke RSUD Kabupaten Kepulauan Meranti pada Sabtu (31/3/2018) siang. Dari hasil tes urine di RSUD Meranti, ternyata urine anaknya positif Methafetamin dan Amphetamin. Ika terkejut mengetahui anaknya positif narkoba. Bahkan bukan anaknya saja yang positif narkoba, setelah urine Ika dites, Ika juga positif mengandung narkoba. Saat Sat Res Narkoba melakukan tes urine Ika, urinenya positif juga. Saat itu ia memang ada

\footnotetext{
${ }^{9}$ https://www.pom.go.id
}

mencicipi sedikit permen yang dibeli oleh anaknya. ${ }^{10}$

b. Es Kepal

Siswa Sekolah Dasar Negeri (SDN) Pakis VIII Surabaya, Jawa Timur, diduga keracunan jajanan es kepal yang dibeli di kantin sekolahnya. Ada sembilan siswa yang saat ini telah dilarikan ke Puskesmas Pakis, untuk menjalani perawatan.Informasi yang didapat Suara.com, sembilan siswa tersebut diduga keracunan setelah meminum jajanan es kepal yang dibelinya di kantin sekolah di Jalan Bintang Diponggo, Surabaya. Anak-anak tersebut muntah-muntah setelah jam istirahat usai.

c.Permen parago narkoba

Beredarnya isu adanya permen mengandung narkoba di Bogor, ternyata sudah sampai ke telinga para pedagang di Sukabumi. Tapi meski begitu, permen jenis Parago Milk ini tetap saja laku dipasaran.

Dari pantauan Radar Sukabumi (Grup Pojokjabar), jajanan anak tersebut masih terpajang di beberapa toko salah satunya di toko yang ada di Jalan Stasion Timur, Kota Sukabumi.Sedikitnya 10 pak permen

\footnotetext{
${ }^{10}$ www.bangka.tribunnews.com
} 
bermerek Parago Milk tersebut terpajang di rak toko. Sang pemilik mengaku, jajanan tersebut memang banyak diminati para konsumen. Sehingga, setiap per dua hari sedikitnya 16 pak terjual.Permen yang diduga mengandung narkoba beredar di sekolah-sekolah di Kota Bogor. Permen tersebut diketahui bermerek Parago dengan beberapa varian rasa seperti jeruk dan mint.Bahkan, informasinya sudah ada siswa salah satu SD yang menjadi korban narkotika berbalut jajanan anak itu. Korban diketahui bernama KN dan NS murid SDN Panaragan 1 Kota Bogor.Ketika dikonfirmasi, pihak SDN Panaragan 1 Kota Bogor membenarkan dua muridnya telah menjadi korban permen Parago. Akibat dari mengkonsumsi permen tersebut, dua muridnya itu mengalami gejalagelaja tidak biasa yaitu tidur seharian serta dada sesak. Mohamad Wahyu, Kepala SDN Panaragan 1 Kota Bogor mengatakan bahwa permen tersebut dijual di lingkungan sekolah. Namun kini sudah diamankan.

a) Permen Dot
BNN: Permen Dot Tidak Mengandung Narkoba tapi Berpotensi Akibatkan Penyakit Kanker, jika dikonsumsi dalam jangka lama, permen ini akan berpotensi mengakibatkan penyakit kanker Hal itu karena permen dot mengandung zat pewarna dan pengawet kimia yang tinggi.

b) Kematian akibat minuman es Sovi Maesaroh (11), siswi kelas V SD Negeri Tanjungpura, Kecamatan Rajapolah, Kabupaten Tasikmalaya. Sovi, demikian dia akrab disapa. Tanpa diduga, dia meninggal sesaat setelah jajan minuman dingin dari pedagang di sekolahnya, Rabu (27/2/2019) kemarin.

Informasi tersebut ramai diperbincangkan warga, khususnya para orang tua yang memiliki anak usia sekolah dasar. Warga merasa khawatir akan jajanan yang sering dibeli anak-anaknya.

Dari keterangan warga, pada hari itu Sovi berangkat sekolah seperti hari-hari 
biasanya dengan diantar ibunya, Nyonya Entin. Pukul $07.00 \mathrm{Wib}$, lonceng jam masuk kelas berbunyi. Sovi pun masuk kelas dan duduk dibangku. Bahkan sempat ngobrol dengan temantemannya.Namun tidak lama kemudian, kondisi raut muka Sovi menjadi berubah yakni pucat dan badannya bergemetar seolah menahan rasa sakit. Tidak lama kemudian, Sovi pun tak sadarkan diri.

Mengetahui kondisinya itu, selanjutnya guru Sovi segera membawanya ke Puskesmas Rajapolah. Dari mulut korban mengeluarkan cairan kental, langsung mendapatkan penangan medis dari petugas medis.

Namun, menurut temanteman korban bahwa sehari sebelumnya yakni, Selasa (26/2/2019) sempat jajan minuman es rasa anggur bersama korban. Jajanan itu dibeli dari pedagang kaki lima yang berada di sekolah.

\section{Hasil Wawancara dengan BPOM}

1. Apakah BPOM memiliki standard operation procedure atau petunjuk teknis dalam melakukan pengawasan atas peredaran obat dan makanan, baik sebelum dan sesudah dipasarkan?

BPOM merupakan lembaga pemerintah, BPOM bertanggung jawab secara langsung kepada presiden, artinya adalah lembaga yang independen. Tugas dan fungsinya adalah mengawasi obat dan makanan. Tentunya BPOM memiliki Standard Operation Procedure seperti yang tertulis dalam peraturan kepala badan pengawas obat dan makanan Pasal 7, Pasal 8, Pasal 11, Pasal 12.

Pre Market, BPOM melakukan evaluasi, misalnya pengusaha/ industri ingin mengimport mereka harus mengajukan ke BPOM terkait apa yang akan di industri/di import. Pengusaha tersebut harus mengajukan data data 


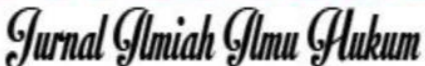

Volume 17, No. 1, Juni 2019

yang akan di evaluasi oleh BPOM.

BPOM melakukan penilaian terhadap makanan tersebut sebelum akhirnya turun izin edar, diuji mutu, kualitas, keamanan dan lain-lain. Apabila sudah memenuhi syarat, mendapat nomor pendaftaran lalu izin edar di urus di BPOM deputi 3 bagian pangan olahan. Setelah mendapat izin edar, sudah dapat mengedarkan, memproduksi/ mengimpor.

Post Market, BPOM melakukan pengawasan setelah diedarkan, misalkan ada hal-hal yang melanggar peraturan diberi sanksisanksi administratif sampai dengan penghentian sementara produksi menggandeng kepolisian setempat. Semisal ada ditemukan di dalam lapangan produk tanpa izin edar, maka BPOM menarik barang tersebut, dimusnahkan dan pelaku usaha di denda.

2. Persyaratan apa saja yang harus dipenuhi pelaku usaha terkait dengan rencana peredaran pangan obat dan makanan (pre market)?

Mendaftarkan produk kepada BPOM, diuji mutu dan kelayakan produknya sampai dengan mendapat izin edar.

3. Persyaratan apa saja yang harus dipenuhi pelaku usaha terkait dengan rencana peredaran pangan obat dan makanan (post market)?

Menjaga kualitas produk selalu sesuai dengan standard kelayakan pangan berdasarkan BPOM.

4. Apakah terdapat perlakuan khusus oleh BPOM dalam hal peredaran jajanan anak sekolah?

Ya tentu, karena Pangan Jajanan Anak Sekolah sendiri merupakan proyek prioritas sesuai aturan kepala Badan Pengawas Obat danMakanan. Badan Pengawas Obat dan Makanan mengadakan Proyek Prioritas Nasional Peningkatan Konsumsi Pangan Sehat Intervensi Keamanan Pangan Jajanan Anak Sekolah selanjutnya di realisasikan dengan program kantin sehat. Ada pula upaya gerakan GENPOPA Generasi Peduli Obat dan Pangan Aman, mengedukasi kepada anak dan remaja apa itu pangan, apa itu jajanan yang sehat, bagaimana ciri jajanan aman dan sehat dan sebagainya. Sudah juga melakukan 
program KIE, Komunikasi Informasi

Edukasi kepada anak anak sekolah diseluruh Indonesia melalui balai POM.

5. Bagaimana masuknya/munculnya kasus pelanggaran atas peredaran jajanan anak sekolah? Apakah hasil dari laporan masyarakat atau inisiatif BPOM yang menyelidiki?

Ada hasil langsung dari laporan masyarakat, ada yang ke BPOM langsung ada yang ke BPKN lalu BPKN sebagai mitra kerja menginfokan kepada BPOM. Ada pula dari hasil pengamatan BPOM dan segera ditindak lanjuti.

6. Terkait dengan ditariknya/ dihimbau untuk menghentikan peredaran permen jeli stik di Kendal pada Oktober 2018 apa yang menjadi dasar pertimbangan?

Tentunya yang menjadi dasar pertimbangan karena adanya berita terkait, keracunan beberapa siswa di Kendal, ada unsur membahayakan maka memang harus ditarik, artinya hal tersebut merupakan kewajiban dan wewenang BPOM untuk mengobservasi dan menguji serta menangani kasus terkait, tentunya juga bekerjasama pula dengan pihak kepolisian. BPOM juga sudah melakukan public warning melalui televisi, koran, media sosial, dan lainnya untuk tidak mengkonsumsi pangan tersebut dan ditayangkan pula dalam website BPOM.

7. Bagaimana proses penanganan berikutnya dan bagaimana bentuk sanksi yang diterapkan selanjutnya? Sejauh ini masih dalam tahap penarikan permen tersebut dari pihak pelaku usaha (penjual) baik toko maupun pedagang kaki lima dan larangan izin edar. Apabila pelaku usaha ada maka akan dilakukan penegakan hukum secara pro justitia secara pidana, sedangkan ke pelaku usaha tahap pedagang kaki lima diberikan edukasi, penyuluhan, pembinaan. Apabila produk tersebut sebenernya sudah terdaftar di BPOM maka akan ditarik, dimusnahkan sampai dengan denda. Apabila tidak terdaftar maka hal tersebut adalah ranah POLRI untuk menyelidiki.

8. Menurut pemberitaan media ditemukan peredaran jajanan anak sekolah yang mengandung bahan kimia berbahaya seperti permen dot, permen penguin 'happy feet', permen jari, permen bungkus cokelat dan lain 
lain, bagaimana penindakan terhadap konsumen yang notabenenya adalah anak-anak setelah mengkonsumsi jajanan tersebut dan merasakan dampak langsung? (Sakit, keracunan, kematian dll)

Penindakan yang diberikan dari pihak BPOM yaitu berupa observasi jajanan anak sekolah terkait hingga menarik dan mencabut izin edar serta bekerjasama dengan pihak kepolisian terkait upaya pencarian pelaku usaha dan penindakan selanjutnya kepada sumber pelaku usaha apabila terbukti melanggar Undang-Undang No 8 tahun 1999 serta khususnya pelanggaran terhadap peraturan kepala badan pengawas obat dan makanan. BPOM tidak bisa memberikan ganti rugi secara materi, hal tersebut bukan kewajiban BPOM. BPOM memfasilitasi, mengusahakan memanggil pelaku usaha apabila ada, menyarankan ke BPSK untuk tuntutan ganti rugi dan lain lain, atau ke YLKI. Saat ini baru ada rancangan Undang-Undang POM yang nantinya memuat ganti rugi tanggungan.
9. Bagaimanakah upaya mencari sumber pelaku usaha?

Bekerjasama dengan pihak kepolisian untuk mencari sumber pelaku usaha. Merupakan ranah tugas POLRI untuk mencari dan menyelidiki pelaku usaha.

\section{Analisis}

Berdasarkan uraian dalam bab-bab sebelumnya dapat dikemukakan uraian analisis oleh Penulis. BPOM memiliki kewenangan berdasarkan pasal 2 pada Peraturan Presiden Nomor 80 Tahun 2017 tentang Badan Pengawas Obat dan Makanan. Pada sebelum produk dipasarkan (Pre Market), BPOM melakukan evaluasi, misalnya pengusaha/ industri ingin meng-import mereka harus mengajukan ke BPOM terkait apa yang akan di industri/di import. Pengusaha tersebut harus mengajukan data data yang akan di evaluasi oleh BPOM. ВРОМ melakukan penilaian terhadap makanan tersebut sebelum akhirnya turun izin edar, diuji mutu, kualitas, keamanan dan lain-lain. Apabila sudah memenuhi syarat, mendapat nomor pendaftaran lalu izin edar di urus di BPOM deputi 3 bagian 
pangan olahan. Setelah mendapat izin edar, sudah dapat mengedarkan, memproduksi/ mengimpor. Maupun ketika sudah dalam pemasaran (Post Market), BPOM melakukan pengawasan setelah diedarkan, misalkan ada hal-hal yang melanggar peraturan diberi sanksi-sanksi administratif sampai dengan penghentian sementara produksi menggandeng kepolisian setempat. Semisal ada ditemukan di dalam lapangan produk tanpa izin edar, maka BPOM menarik barang tersebut, dimusnahkan dan pelaku usaha di denda.

Dalam hal penyuluhan dan programprogram kemasyarakatan pun BPOM sudah melakukan fungsi dengan sangat baik, dan banyak sekali melakukan gerakan-gerakan yang mengedukasi masyarakat terkait tentang Pangan Jajanan Anak Sekolah bahkan Pangan Jajanan Anak Sekolah sendiri merupakan proyek prioritas sesuai aturan kepala Badan Pengawas Obat dan Makanan. Badan Pengawas Obat dan Makanan mengadakan Proyek Prioritas Nasional Peningkatan Konsumsi Pangan Sehat Intervensi Keamanan
Pangan Jajanan Anak Sekolah ( PJAS ) selanjutnya di realisasikan dengan program kantin sehat.

Ada pula upaya gerakan GENPOPA, Generasi Peduli Obat dan Pangan Aman, mengedukasi kepada anak dan remaja apa itu pangan, apa itu jajanan yang sehat, bagaimana ciri jajanan aman dan sehat dan sebagainya. Sudah juga melakukan program KIE, Komunikasi Informasi Edukasi kepada anak anak sekolah diseluruh Indonesia melalui balai POM. Tidak hanya anak-anak sekolah ataupun masyarakat sebagai konsumen saja yang diberikan penyuluhan dan di edukasi oleh BPOM bahkan pedagang kaki lima, pedagang kantin anak sekolah pun diberikan edukasi dan penyuluhan mengenai apa itu produk-produk layak konsumsi, aman dan sehat.

BPOM menerima dan melayani aduan masyarakat baik melalui halo BPOM, email, maupun aduan secara langsung. Namun tidak hanya hal itu, BPOM pun terus bergerak dalam rangka menjalankan tugas dan fungsinya mengawasi peredaran makananan dan obat khususnya dalam hal ini Pangan Jajanan Anak 
Sekolah, apabila diketemukan dalam masyarakat makanan-makanan yang tidak sesuai standard dan mutu BPOM, misalnya dari segi kemasan, tanggal kadaluwarsa, tanpa izin edar baik di pedagang kecil sampai swalayan modern sekalipun BPOM berhak mengusut dan menanyakan mengenai produk tersebut, menarik dan memberhentikan peredarannya bahkan sampai pemusnahan dan denda terhadap pelaku usaha, sedangkan apabila dalam hal-hal tersebut pelaku usaha tidak dan/atau belum ditemukan, dalam hal ini BPOM bekerjasama dengan POLRI diseluruh Indonesia. BPOM memiliki $M o U$ tersendiri bersama POLRI dalam menjalankan fungsi pengawasan. Menjadi tugas dan fungsi POLRI dalam hal penyelidikan terhadap pelaku usaha yang belum ditemukan.

Ada pula upaya gerakan GENPOPA Generasi Peduli Obat dan Pangan Aman, mengedukasi kepada anak dan remaja apa itu pangan, apa itu jajanan yang sehat, bagaimana ciri jajanan aman dan sehat dan sebagainya. Sudah juga melakukan program KIE, Komunikasi Informasi
Edukasi kepada anak anak sekolah diseluruh Indonesia melalui balai POM, juga melakukan pengedukasian kepada pelaku usaha kelas bawah seperti pedagang kaki lima yang berada di lingkungan sekolah. Adanya laporan dan aduan yang masuk ke BPOM terkait kasus keracunan Permen Jeli Stik di Kendal menjadi dasar pertimbangan ditariknya permen tersebut dari masyarakat, dan ada unsur membahayakan maka memang harus ditarik, artinya hal tersebut merupakan kewajiban dan wewenang BPOM untuk mengobservasi dan menguji serta menangani kasus terkait, tentunya juga bekerjasama pula dengan pihak kepolisian. BPOM juga sudah melakukan public warning melalui televisi, koran, media sosial, dan lainnya untuk tidak mengkonsumsi pangan tersebut dan ditayangkan pula dalam website BPOM.

Selama ini seringkali masih banyak sekali kasus konsumen terjadi terkait Pangan Jajanan Anak Sekolah berdasarkan hasil penelitian penulis, sebenarnya dikarenakan akibat tiga pilar SisPOM itu sendiri yang belum 
bekerja secara maksimal, baik secara pribadi untuk kepentingan sendiri maupun 'kerjasama' satu dengan yang lain untuk kepentingan bersama. Misalnya seperti konsumen itu sendiri yang tidak/ kurang berhati-hati dalam memilah dan memilih pangan yang akan mereka konsumsi, rendahnya pengetahuan serta sikap tidak peduli terhadap keselamatan dan kesehatan diri sendiri. Selain itu dari pihak pelaku usaha, pelaku usaha pun sering kali bahkan sangat banyak yang tidak peduli dengan produk yang mereka jual, baik dari segi kualitas kelayakan konsumsu, gizi maupun kesehatan. Sering kali pelaku usaha hanya mementingkan profit dari hasil penjualan tanpa memikirkan dampak bagi orang lain kedepannya sampai pada hal terkait kesehatan dan nyawa orang lain. Pelaku usaha banyak sekali yang dengan sadar menjual produk-produk yang kurang layak konsumsi bahkan tidak layak konsumsi, baik dari mutu, gizi dan kesehatan.

Ada pula pelaku usaha yang memperbaiki mutu/ membuat komposisi produknya sesuai standard kelayakan BPOM namun hanya sekedar untuk lolos izin edar dari BPOM setelah itu merubah komposisi produk menjadi tidak sesuai sebagaimana awal mula mereka mendaftarkan kepada BPOM, di lain hal ada pula pelaku usaha yang tidak sadar bahwa produknya telah di plagiarisme/di duplikasi dengan produk-produk serupa oleh oknum-oknum tidak bertanggung jawab sehingga merugikan pelaku usaha itu sendiri dan juga tentunya konsumen apabila konsumen sampai salah memilih produk yang palsu tersebut.

Hal yang ketiga adalah BPOM sendiri, BPOM sudah menjalankan tugas dan wewenang dengan baik namun memang belum maksimal. Dalam arti BPOM harus lebih gencar lagi melaksanakan operasional pengawasan. Mengusut tuntas produk-produk terkait, ditarik dari peredaran, dimusnahkan, di beritakan dengan gencar, memberi penyuluhan kepada pelaku usaha kecik (pedagang kaki lima), konsumen, juga menindak dan memberikan sanksi administratif kepada pelaku usaha dengan tegas, serta 
bekerjasama dengan POLRI secara lebih aktif dalam rangka mencari pelaku- pelaku usaha yang sering kali pula tidak terdeteksi siapakah dalang dibalik semua produk-produk terkait. Dasar hukum pengawasan obat dan makanan masih bersifat sangat umum sehingga dibutuhkan Undang-Undang Pengawasan Obat dan Makanan yang bersifat khusus (lex specialis). Belum adanya Undang-Undang yang secara khusus mengatur pengawasan Obat dan Makanan, maka BPOM mengajukan rancangan undang-undang. Rancangan Undang-Undang (RUU) Pengawasan Obat dan Makanan saat ini telah masuk dalam Prolegnas Tahun 2018, sehingga BPOM harus mengawal tindak lanjutnya. Perkuatan yang diharapkan dapat dikukuhkan melalui Undang-Undang Pengawasan Obat dan Makanan sebagai berikut: 1. Pengembangan, pembinaan, dan fasilitasi Industri Obat dan Makanan dalam rangka peningkatan daya saing, melalui pembinaan dan pemberian bimbingan teknis bagi pelaku usaha agar mampu memenuhi ketentuan persyaratan dan peningkatan jaminan kemudahan berusaha; 2. Peningkatan Efektifitas dan Penguatan Pengawasan Obat dan Makanan, melalui penguatan kewenangan BPOM dalam pengawasan Obat dan Makanan yang full spectrum; dan 3. Perkuatan fungsi Penegakan hukum untuk kejahatan di bidang Obat dan Makanan, melalui pemberian sanksi Pengawasan Obat dan Makanan dapat menimbulkan efek jera dan perkuatan kewenangan PPNS Badan POM.

Undang-Undangan Nomor 18 Tahun 2012 tentang Pangan selanjutnya disebut UU Pangan diundangkan pada tanggal 17 November 2012. Dengan adanya undang-undang ini, maka terbukalah saluran hukum bagi konsumen untuk menuntut ganti rugi ketika mendapat kerugian akibat mengkonsumsi pangan yang menimbulkan kerugian terhadapnya. Namun banyak hal seperti yang sudah penulis kemukakan diatas yaitu hambatan-hambatan bagi konsumen untuk menuntut sebuah ganti rugi, baik dari segi konsumen yang memang berasal dari golongan uneducated people maupun sebagainya. 


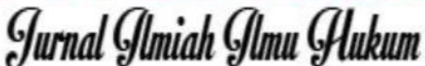

Volume 17, No. 1, Juni 2019

Sehubungan dengan pengadaan pangan yang dimaksud pula, tidak akan tertutup kemungkinan beredarnya kembali dan terus menerus pangan yang tidak memenuhi syarat kesehatan yaitu, aman, bermutu, dan bergizi sehingga dapat menimbulkan kerugian bagi konsumen.

Pasal 93 UU Pangan tersebut juga sudah sangat jelas memuat mengenai aturan dan sanksi bagi setiap orang yang melanggar standar dan mutu pangan. Namun kembali seperti yang penulis kemukakan, bahkan sering kali pelaku usahanya saja tidak dapat diketemukan namun produk-produk berbahaya tersebut tetap bisa beredar selang beberapa waktu kemudian setelah mungkin sempat ditertibkan, bisa saja kembali beredar dengan merek berbeda atau bahkan dengan produk dan merek yang sama persis dan dibiarkan begitu saja, padahal nyata dan fakta beredar di lingkungan masyarakat, namun tidak dipedulikan seolah bukan suatu hal yang berarti atau harus ditangani. Pada dasarnya memang tidak mudah untuk mensosialisasikan UUPK. Sebagian masyarakat memang ada yang tidak peduli untuk menuntut hak-haknya, karena itu banyak konsumen yang sering dirugikan oleh produsen karena ketiadaan informasi ataupun informasi yang kurang transparan. Namun, sesuai dengan apa yang tertuang pada Pasal 5 Undang-Undang Nomor 8 Tahun 1999 tentang Perlindungan Konsumen, kewajiban konsumen sangat jelas. Selain membaca atau mengikuti petunjuk informasi dan prosedur pemakaian atau pemanfaatan barang dan/atau jasa demi keamanan dan keselamatan untuk kepentingan konsumen sendiri. Selain itu lemahnya perlindungan konsumen di Indonesia juga salah satunya berakar dari UU Perlindungan Konsumen yang juga tidak tegas mengatur mediasi antara pihak-pihak terkait. Di beberapa negara, lembaga mediasi tersebut dikenal dengan smile claims court, dengan kedudukan mandiri atau di bawah pengadilan. Jika di Indonesia, diatur dalam UU nomor 8 tahun 1999 yang menyerahkan mediasi konsumen dengan produsen kepada Badan Penyelesaian Sengketa Konsumen (BPSK). 


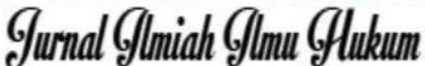

Volume 17, No. 1, Juni 2019

Lebih lanjut lagi lembaga ini belum mempunyai aturan khusus yang mengatur dan hanya menginduk kepada UU. Kekurangan kedua, putusan yang dibuat BPSK tidak mempunyai daya ikat memaksa yang bersifat final, sehingga pihak yang dikalahkan oleh konsumen tidak mau melaksanakan putusan, bahkan mengambil langkah hukum di pengadilan umum, padahal seharusnya BPSK melindungi kerugian yang diderita konsumen dengan proses cepat dan putusan harus ditaati semua pihak. Singapura dan Malaysia telah menerapkan small claims court yang setiap keputusannya disegani dan ditaati oleh produsen dan penjual. Seperti di Singapura, antara produsen dan konsumen posisinya sederajat. Dengan tingkat ketaatan hukum atas putusan small claims court sangat tinggi.

Sistem perlindungan konsumen yang diatur dalam UUPK terasa tidak lagi memadai khususnya dihadapkan pada perkembangan zaman di era ekonomi digital. Pendekatan lintas sektoral dan kewilayahan tidak lagi memadai dalam melindungi kepentingan konsumen. Sebab, konsumen yang sudah berdayalah bisa menjadi pendorong pertumbuhan ekonomi. Perlindungan konsumen menjadi issue multi facets dari multisektor yang memerlukan pengaturan dan penanganan yang menyeluruh. ${ }^{11}$ Begitu pula dengan pasal 140 UU Pangan ini, faktanya pelaku usaha bisa bermain 'nakal' dengan oknum pemerintah yang tidak bertanggung jawab pula. Pelaku usaha sering kali tetap bisa mengedarkan produk-produk berbahaya tersebut atau lebih parahnya lagi produk tersebut dibiarkan beredar ditengah masyarakat seolah bukan menjadi suatu problema bagi masyarakat, melainkan melulu masyarakat yang dituntut untuk selalu melindungi dirinya sendiri. Ada pula hal lainnya, pemerintah hanya menarik sementara atau memberhentikan izin edar sementara, sedangkan hal ini sebetulnya dirasa sangat meresahkan dan merugikan konsumen, sebab kerap kali pelaku usaha tetap mengulangi kesalahan yang sama, mereka tidak sama sekali

\footnotetext{
${ }^{11}$ Www.detik.com
} 


\section{Gurnal Glmiah Glmu Glukum}

Volume 17, No. 1, Juni 2019

memperbaiki produk barang dan/atau jasa mereka, malah cenderung secara diam-diam tetap memproduksi dan mengedarkan produk tersebut di tengah masyarakat tanpa memperdulikan ketentuan undangundang dan pemerintah.

Dalam Undang-Undang Nomor 18 Tahun 2012 juga banyak sekali terdapat sanksi administratif dan pidana yang tertuang. Namun disayangkan, tidak ada pasal-pasal yang mengatakan kewajiban pemerintah untuk melakukan pembinaan kepada pelaku usaha. Di dalam UU Nomor 18 Tahun 2012 pada pertimbangannya menyatakan pemenuhan pangan adalah bagian dari HAM yang dijamin UndangUndang Dasar 1945. Namun, dalam ketentuan umum UU itupun tidak ada definisi hak atas pangan, dan yang paling jelas adalah tidak adanya tanggung gugat jika terjadi pelanggaran hak atas pangan. Selain itu lemahnya perlindungan konsumen di Indonesia juga salah satunya berakar dari UU Perlindungan Konsumen yang juga tidak tegas mengatur mediasi antara pihak-pihak terkait. Di beberapa negara, lembaga mediasi tersebut dikenal dengan smile claims court, dengan kedudukan mandiri atau di bawah pengadilan. Jika di Indonesia, diatur dalam UU nomor 8 tahun 1999 yang menyerahkan mediasi konsumen dengan produsen kepada Badan Penyelesaian Sengketa Konsumen (BPSK).

Lebih lanjut lagi lembaga ini belum mempunyai aturan khusus yang mengatur dan hanya menginduk kepada UU. Kekurangan kedua, putusan yang dibuat BPSK tidak mempunyai daya ikat memaksa yang bersifat final, sehingga pihak yang dikalahkan oleh konsumen tidak mau melaksanakan putusan, bahkan mengambil langkah hukum di pengadilan umum, padahal seharusnya BPSK melindungi kerugian yang diderita konsumen dengan proses cepat dan putusan harus ditaati semua pihak. Singapura dan Malaysia telah menerapkan small claims court yang setiap keputusannya disegani dan ditaati oleh produsen dan penjual. Seperti di Singapura, antara produsen dan konsumen posisinya sederajat. Dengan tingkat ketaatan hukum atas 
putusan small claims court sangat tinggi.

\section{III.PENUTUP}

\section{A. Kesimpulan}

Berdasarkan penelitian penulis dapat dikemukakan kesimpulan oleh Penulis. Bentuk pengawasan yang sudah dilakukan oleh BPOM terkait kasus Permen Jeli Stik di Kendal adalah sudah menjalankan standard operation procedure sesuai aturan kepala BPOM baik secara pre market maupun post market. Pangan Jajanan Anak Sekolah sendiri sudah merupakan proyek prioritas sesuai aturan kepala Badan Pengawas Obat dan Makanan. Badan Pengawas Obat dan Makanan mengadakan Proyek Prioritas Nasional Peningkatan Konsumsi Pangan Sehat Intervensi Keamanan Pangan Jajanan Anak Sekolah ( PJAS ) selanjutnya di realisasikan dengan program kantin sehat.

Perlindungan hukum bagi konsumen atas peredaran jajanan anak sekolah sudah tertuang dan termasuk didalam Undang-Undang Nomor 8 Tahun 1999 tentang perlindungan konsumen, Undang-Undang Nomor 18 Tahun 2012 tentang Pangan.
Perlindungan hukum terhadap konsumen mengatur tentang setiap konsumen mempunyai hak atas keamanan dalam mengkonsumsi barang dan/atau jasa dan hak atas informasi yang benar, jelas dan jujur mengenai kondisi dan jaminan barang dan /atau jasa. Pengusaha sebagai penyedia barang dan jasa kurang memperhatikan kewajibannya dan hak-hak konsumen, begitu juga masyarakat tidak terlalu mempedulikan haknya sebagai konsumen. Padahal dalam UndangUndang Perlindungan Konsumen dinyatakan secara rinci hak-hak masyarakat selaku konsumen.

\section{B.Saran}

Kepada Pemerintah (BPOM), harus lebih mengoptimalkan tugas dan fungsi sebagai pengawas obat dan makanan, dan meningkatkan kinerja semaksimal mungkin. Semakin cekatan dalam proses perlindungan dan pelayanan kepada masyarakat terkait peredaran pangan, serta terus menjaga relasi dan bekerjasama dengan baik dengan mitra kerja seperti POLRI, BPKN, BPSK, dan YLKI, juga selalu mengaktualkan 


\section{Glunal Glmiah G/lmu Gflukum}

Volume 17, No. 1, Juni 2019

kegiatan- kegiatan edukasi kepada masyarakat.

Kepada Pelaku Usaha, menaati segala prosedur dan syaratsyarat izin edar pangan olahan sesuai dengan regulasi yang ada. Menjaga kualitas pangan agar tetap terjaga mutu dan gizi pangan yang berkualitas sesuai standard BPOM, serta selalu melakukan fungsi pengawasan terhadap produknya sendiri, menaati kewajiban sebagai pelaku usaha dan menperhatikan hak-hak konsumen, mengawasi produk-produk usaha baik dalam segi kestabilan kualitas dari proses pembuatan sampai peredaran, maupun dijaga dari segala bentuk pemalsuan-pemalsuan produk serupa yang merugikan pihak pelaku usaha sendiri juga konsumen.

Kepada Konsumen, harus selalu cerdas dan berhati-hati memilih produk pangan yang hendak dikonsumsi, terutama terkait Pangan Jajanan Anak Sekolah, perhatikan dan cermati secara teliti produk mana yang sekiranya layak dan aman untuk di konsumsi, tidak sembarang membeli dan mengkonsumsi demi kenyamanan dan keselamatan diri sendiri.

\section{DAFTAR PUSTAKA}

\section{A. BUKU}

Abdulkadir, Muhammad. Hukum dan Penelitian Hukum. (Bandung: PT. Citra Aditya Bakti, 2004).

Advendi, Elsi. Hukum Dalam Ekonomi.

(PT

Grasindo:Jakarta,2007).

H.S, Salim. Pengantar Hukum Perdata Tertulis $(B W)$. (Jakarta: PT. Sinar Grafika, 2008).

J, Vredenbregt. Metode dan Teknik Penelitian Masyarakat. (Jakarta: Gramedia, 1981).

Kadarisman,M. Manajamen Pengembangan Sumber Daya Manusia.(Jakarta: Rajawali,2013).

Kalsen, Hans. Teori Umum tentang Hukum dan Negara. (Bandung: PT. Raja Grafindo Persada, 2006).

Kristiyanti, Celina Tri Siwi. Hukum Perlindungan konsumen. (Jakarta: PT. Sinar Grafika, 2008).

Prawirohamidjojo, R. Soetojo dan Marthalena Pohan, Hukum Perikatan. (Surabaya: Bina Ilmu, 1984). 
Rahardjo, Satjipto. Ilmu Hukum. (Bandung: PT. Citra Aditya Bakti, 2000).

Rasjidi, Lili dan I.B Wysa Putra. Hukum Sebagai Suatu Sistem. (Bandung : Remaja Rusdakarya, 1993).

Sasongko, Wahyu. Ketentuanketentuan Pokok Hukum Perlindungan Konsumen. (Bandar Lampung: Penerbit Universitas Lampung, 2007).

\section{Shidarta. Hukum Perlindungan Konsumen Indonesia. (Jakarta: PT Grasindo, 2006).}

Simbolon, Maringan Masry. Dasar-Dasar Administrasi dan Manajemen. (Jakarta: Ghalia Indonesia, 2004).

Soekanto, Soerjono. Pengantar Penelitian Hukum. (Jakarta: Universitas Indonesia, 1986).

Penelitian Hukum. Cetakan ke-3. (Jakarta: UI press, 2006).

Suherman, E. Aneka Masalah Hukum

Kedirgantaraan. (Himpunan Makalah 1961-1995). (Bandung: Mandar Naju, 2000).

Sutedi, Adrian, Tanggung Jawab Produk Dalam Huku Perlindungan Konsumen. (Bogor: Ghalia Indonesia,2008), hal. 4.
Widjaja, Gunawan dan Ahmad Yani, Hukum Perlindungan Konsumen. (Jakarta: PT. Gramedia Pustaka Utama, 2000), hal. 59.

$$
\begin{array}{cr}
\text { Yin, Robert K. Case Study } \\
\text { Research: } & \text { Design and } \\
\text { Menthods. } & \text { (California: } \\
\text { SAGE } & \text { Publications, } \\
\text { Inc.,1989). } &
\end{array}
$$

\section{B.Kamus}

Departemen Pendidikan Nasional, Kamus Besar Bahasa Indonesia (Jakarta: Balai Pustaka,2005)

\section{C.Undang-Undang}
Indonesia. Kitab Undang- Undang Hukum Perdata. Pasal 1367. Peraturan Presiden

Nomor 80 Tahun 2017. .Peraturan

BPOM

Nomor 12 Tahun 2018. .Undang-Undang No.8 Tahun 1999 tentang Perlindungan Konsumen. .Undang-Undang No.18 Tahun 2012 tentang Pangan.

\section{D.Website}

https://dinkes.probolinggokota.g o.id

https://www.pom.go.id https://www.bangka.tribunnews. com

https://www.polres.jateng.go.id https://m.detik.com 